\title{
舞台芸術施設の運営組織と自主事業の有無の時系列変化に関する研究 A STUDY ON THE LONGITUDINAL CHANGE OF MANAGEMENT ORGANIZATION AND WHETHER OR NOT INDEPENDENT PRODUCTIONS OF FACILITIES FOR PERFORMING ARTS
}

\author{
高木俊行*, 清水裕之**, 守屋秀夫***, 小野田 泰明**** \\ Toshiyuki TAKAGI, Hiroyuki SHIMIZU, Hideo MORIYA \\ and Yasuaki ONODA
}

\begin{abstract}
The aim of this study is to collect more accurate data on operation and management of facilities for performing arts, through a similar questionnaire survey conducted with 1995 as the target year (the first 1986, the second 1990 as the target year ), and to analyze the longitudinal change on three times finally. In this paper we report the longitudinal change of management organization and whether or not independent productions especially. The change of management organization is due to the lack of legal basis for public halls and the field of art culture. Management organization and whether or not independent productions and those relations differ from opening period, complex, name, capacity and size.
\end{abstract}

\author{
Keywords : Facilities for Performing Arts, Management Organization, whether or not Independent Productions, \\ the Longitudinal Change, Questionnaire Survey \\ 舞台芸術施設, 運営組織, 自主事業の有無, 時系列変化, アンケート調査
}

\section{1. 研究の背景と目的}

生活水淮の高度化や余暇時間の増大等を背景に劇場・ホールなど の舞台芸術施設は全国各地で盛んに建設されてきたが、ハードとし ての施設の整備が進む一方で、ソフトすなわち運営面に対する認識 が不足していることから、施設を十分に活用できていないといった 問題が生じている。また心の豊かさを求める人々の価值基準の変化 や文化一の関心の高まりを反映して、施設利用者の施設に対する要 求も多様化している。従って、これら多様化した要求に応えるため にも、運営面に対する理解の促進とこれを具体化する有効な施策の 実施が是非とも必要である。さらに、21世紀の高齢社会などの社会 構造の変化に対応して、今後は地域の独自性や主体性を確立すると ともに、様々な分野の人々のネットワークを活用しながら、地域住 民が一体となって施設を支えていく姿勢が必要ではないかと思われ る。従って、既存の施設の利用を促進するとともに、新たに施設を 建設する際、計画段階から運営面を含めた総合的な施設計画を立案 することが重要であり、既存の施設がどのような運営状況にあるの かを把握する必要性は高いと思われる。しかし、こうした舞台芸術 施設の運営状況における変化を的確に捉え、かつ包括的に把握する ためのデータの蓄積は十分に進んでいるとは言えない。
このような背景のもと、清水等は過去2回、1986年度（昭和61年 度）及び1990年度（平成2年度）を対象年度とする舞台芸術施設の 運営に関するアンケート調査を実施した。第1回目は「舞台芸術施 設の経営に関する研究一劇場施設の経営に関する計量モデルの作成 昭和61-63年度文部省科学研究費補助金、研究代表者：山崎正和」 として、第2回目は「わが国文化・芸術情報の体系化と統計調查方 法の研究一舞台芸術施設の運営経理の処理方法に関する調查、平成 2-3年度文部省科学研究費補助金、研究代表者 : 永山貞則」として それぞれ実施した（以下、1986調査文1) 及び1990調查文3) 文8)）。さ らに今回、平成8-10年度文部省科学研究費補助金・特定領域研究 (旧 称：重点領域研究）「ミクロ統計データ」（領域代表者：松田芳郎） の一環として、1995年度（平成7年度）を対象年度とする第3回目の アンケート調查「ミクロ統計データを活用した舞台芸術施設運営に 関する調查研究、研究代表者：清水裕之」を実施した（以下、1995 調查文4)）。この結果、ほぼ5年ごとの舞台芸術施設の運営状況に おける変化を把握することが可能となった。本研究は、この中から 特に運営組織と自主事業の有無の時系列変化に着目し、その傾向を 把握するとともに、時系列変化に倸る要因を分析することを主な目 的とする。
$*$ 名古屋大学大学院工学研究科建築学尃攻 大学院生.工修

** 名古屋大学大学院工学研究科建築学尃攻 教授. 工博

*** 昭和音楽大学音楽学部音楽芸術運営学科 教授.工博

**** 東北大学大学院工等研究科都市・建築学専攻 助教授・学・博
Graduate Student, Dept. of Architecture, Graduate School of Engineering, Nagoya Univ., M. Eng.

Prof., Dept. of Architecture, Graduate School of Engineering, Nagoya Univ., Dr. Eng.

Prof., Dept. of Music and Arts Administration, Faculty of Music, Showa Univ. of Music, Dr. Eng.

Assoc. Prof., Dept. of Architecture and Building Science, Graduate School of Engineering, Tohoku Univ., Dr. Eng. 
舞台芸術施設の使用状況に関する研究には、清水等が世田谷区内 の区民会館の利用実態を調查したものや文5)、小野田等が仙台市に おける新設ホールによる都市内既存ホールの使用変化を調査したも のなどがある齐。しかし、舞台芸術施設運営全般にわたる包括的 な時系列変化の分析は、継続的なデー夕の蓄積によって今回初めて 可能となるものである。

なお、舞台芸術施設における組織種別は施設の性格を決定づける 重要な要素である。従って、組織種別の変化を分析しその傾向を把 握することは、舞台芸術施設運営を総合的に理解する上で極めて重 要であると言える。組織種別の変化は機構上のあるいは制度上の変 化であるが、組織種別の変更に伴い、中身の職員やその職務内容等 も変化すると思われる。従来のいわゆる硬直的な管理運営から、今 後は市民に開かれたより柔軟な積極的運営に変化していくことが求 められる。従って、運営組織の職員体制や運営システムに応じた機 能空間を備えていることが建築計画学的に重要であり、各室を有機 的に結び付け、時代の変化に適応できるフレキシビリティを確保し ておく必要がある。これは、既存の施設の増改築や新築の際に考虑 すべき視点であると考えられる。

\section{2. 調查の概要}

（1）1986調査 公立文化施設協議会に加盟する全国の公共ホール （県・市民会館、文化会館、劇場等で、民間の劇場、体育館、野外 劇場等は除いた）1,271施設を対象にアンケート調査を実施したも ので、回収数は604施設（座席数が5,000席以上のものが3施設あっ たが、性格が異なるものと判断して集計から除外した）、有効回答 数は601施設である。

（2）1990調査 舞台芸術施設データベースを作成するためのアンケ 一ト調查注1) で回答のあった1,323施設と、回答はなかったが必要と 思われる50施設を合わせた 1,373 施設に対してアンケート調査を実 施したもので、回収数は761施設、有効回答数は753施設である。

（3）1995調査 過去2回、ともに回答のあった340施設を対象にアン ケート調查を実施したもので、回収数は210施設、有効回答数注 207 施設（60.9\%）である（時系列標本）。但し、調查対象は公立の施 設に限られ、民閒の施設は含まれていない(注22) 注3)注4)。

\section{3. 集計の前提}

（1）組織種別 本研究の調査対象は公立の施設に限られることから、 組織種別を「教育委員会」「教育委員会以外の自治体部局」「財団・ 社団法人注5)」「その他の種別注(6)」に分類した。「財団・社団法 人」及び「その他の種別」は、施設の所有者である自治体が管理運 営を外部の機関に委託する形態である。なお、運営組織という語句 は個々の組織種別を総称する場合に用いることとする。

（2）自主事業の有無・1986調查に自主事業の有無を尋ねる設問があ るほか、ホールの年間利用日数に関する設問注7)、自主事業の内容 に関する設問注8)、施設運営の経理に関する設問等から個別に判定 した吝) 好。但しこれは一施設としての判定であり、例えばある 施設が2つのホールを有する場合、第1ホールが「自主事業あり」で 第2ホールが「自主事業なし」でも、一施設としては「自主事業あ り」の判定となる。従って「自主事業あり」の施設でも「自主事業 なし」のホールが存在する。
（3）開館年代 1986 調査に開館年を尋ねる設問があるほか、「舞台 芸術施設データベース（1994.03）文2)」に記載されている開館年を 用いた。本研究のねらいは3回の調查に基づく時系列変化を分析す ることであるため、調查対象は1986調査の調查対象一開館年が1986 年 (昭和61年) 以前の施設一に限られる。従って、分類における1985 年以降（昭和60年代）は1985年及び1986年のみとなる。

(4) 機能構成 運営組織の経理に一体的に組み込まれている機能に

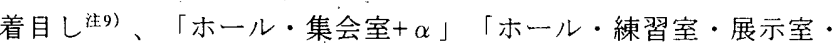

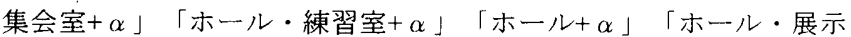

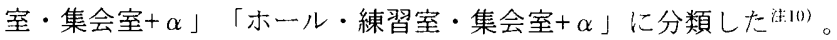
この6つの組み合わせですべての機能構成を分類できる。

（5）施設名称 1995 調査の調査票に記入されている名称を用いた。 $\lceil\cdots$ 公会堂」「…市民会館」「…県民会館」「…区町民会館」 文化会館」「…文化センター」「…公民館」に分類した。この7つ の分類で全体の8割をこえる。

（6）合計客席数 一施設内にホールが1つあるが2つ以上あるかに関 わらず、一施設が有するホールの客席数の和である注11)。3回の調 查ともに1995調查の数値を用いた。

（7）運営床面積 運営組織の経理に組み込まれている部分の床面積、 すなわち運営組織が管理運営している部分全体の床面積を計上する。 3回の調査ともに1995調查の数値を用いた。

\section{4. 組織種別の变化}

図1及び表1に示すように組織種別の個数の変化をみると、数の上 でどの年次も教育委員会の施設が多い。見かけ上、教育委員会及び その他の種別は変化がなく、教育委員会以外の自治体部局が減少し、 財団・社団法人が增加する 形となっている。1995調査 は財団・社団法人が教育委 員会以外の自治体部局を大 きく上回り、教育委員会と ほぼ同数になるところまで 增加している。なお8割の 施設（167施設）の組織種 別は変化していない。また 表2に示すように組織種別 の変化（内訳）をみると、 自治体の直営から財団・社 団法人に種別を変更した施 設が多い(20施設)。教育 委員会以外の自治体部局か ら教育委員会に種別を変更 した施設の多いことも注目 すべき点である(12施設)。 一方、教育委員会から教育 委員会以外の自治体部局に 種別を変更した施設は少な い（4施設）。財団・社団 法人からの変更はない。な お教育委員会の合計は横ば

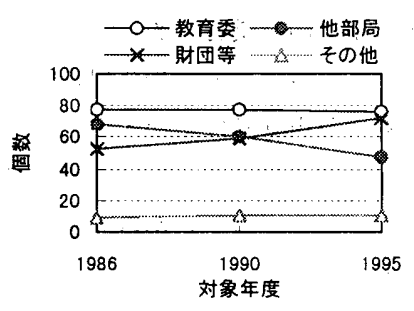

图1組緎種別の個数の変化

\begin{tabular}{|c|c|c|c|c|}
\hline \multicolumn{5}{|c|}{ 表 1 組織種別の個数の变化 } \\
\hline 種別: & 1986 & 1,990 & 1995 & 同已 \\
\hline 教育委 & 77 & 78 & 76 & 63 \\
\hline 他部局 & 69 & 60 & 48 & 44 \\
\hline 財団等 & 52 & 59 & 72 & 52 \\
\hline その他 & 9 & 10 & 11 & 8 \\
\hline 全体 & 207 & 207 & 207 & 167 \\
\hline
\end{tabular}

表2 組辒種別の变化(内郭)

\begin{tabular}{|c|c|c|c|c|}
\hline 1986 & 1990 & 1995 & 個数 & 比率 \\
\hline $87^{2}$ & folin & $8 x^{2} / 17$ & 63 & 364 \\
\hline 教育委 & 教育委 & 他部局 & 3 & 1.4 \\
\hline 教育委 & 他部局 & 他部局 & 1 & 0.5 \\
\hline 敖离瑟 & 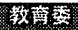 & 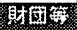 & 5 & 24 \\
\hline 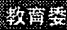 & AtG & 斯田 & 4 & 10 \\
\hline 教育委 & その他 & その他 & 1 & 0.5 \\
\hline 他部局 & 他部筒 & 他部涺说 & 44 & 213 \\
\hline 他部成 & 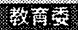 & 教高禖 & 6 & 29 \\
\hline 他部甪 & 他的涪 & 教揞 & 6 & 29 \\
\hline 他部局 & 他能局 & 自才团等 & 8 & 39 \\
\hline 倠部局 & 期國等 & 財団等格 & 3 & 1.4 \\
\hline 他部局 & 他部局 & その他 & 1 & 0.5 \\
\hline 他部局 & その他 & その他 & 1 & 0.5 \\
\hline 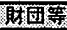 & 㬝目等 & 的团等 & 52 & 25.1 \\
\hline द्विका & z्टिए। & zott: & 8 & 3.9 \\
\hline その地 & 教育委 & 教育委 & 1 & 0.5 \\
\hline 全体 & & & 207 & 100.0 \\
\hline
\end{tabular}



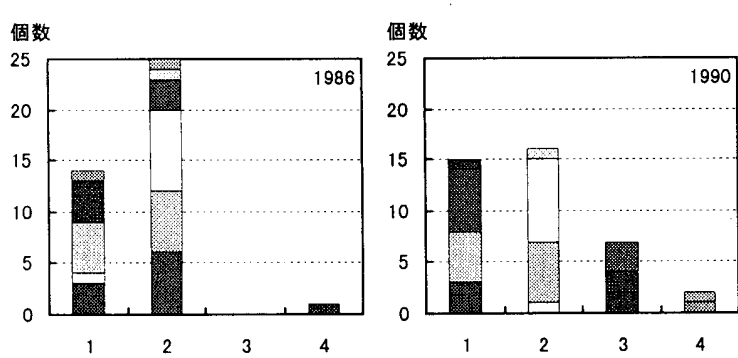

図2 組㼄種別の变化(增墄分)

\begin{tabular}{|l|ccc|c|ccc|}
\hline \multirow{2}{*}{ 組織種別 } & \multicolumn{4}{|c|}{ 自主事業の有無 } & \multicolumn{3}{|c|}{ 無の增減 } \\
\cline { 2 - 9 } & あり & なし & 合計 & ありの比率9 & あり & な & 合計 \\
\hline 教育委 & 61 & 15 & 76 & 80.3 & 3 & -4 & -1 \\
他部局 & 22 & 26 & 48 & 45.8 & -7 & -14 & 21 \\
財団等 & 57 & 15 & 72 & 79.2 & 16 & 4 & 20 \\
その地 & 5 & 6 & 11 & 45.5 & 1 & 1 & 2 \\
\hline 全体 & 145 & 62 & 207 & 70.0 & 13 & -13 & 0 \\
\hline
\end{tabular}

いとなっているが、これは教育委員会から他に種別を変更した施設 (減少分）と他加教育委員会に種別を変更した施設（増加分）の 数がほぼ等しいためである。図2に組織種別の変化（増减分）を示 す。補足調查の結果、自治体の直営加財団・社団法人一の種別の 变更は、地域文化の振興を目的とした文化基本構想の策定及び文化 施設の再編整備に伴って実施されるケースが多く、公務員の労働規 定や配置換、会計年度独立の原則（予算の単年度主義）等、行政の 論理に縛られない柔軟かつ効率的な施設運営と事業展開を図ること ができること、専門職員を計画的に採用できること、自治体職員の 見かけ上の定数削減等が主要な要因として举げられる。

\section{5。自主事業との関連}

表3に自主事業の有無と有無の増减を示したが、1995調査では全 体で7割の施設が自主事業を行っている。これを組織種別との関連 でみると、教育委員会及び財団・社団法人は8割の施設が自主事業 を行っているのに対して、教育委員会以外の自治体部局（及びその 他の種別）は5割に満たない注12)。また組織種別と自主事業の有無 の増減との関連をみると（同表）、教育委員会以外の自治体部局は 21 施設が減少した。特に「自主事業なし」の施設の減少が顕著であ る（14施設）。一方、財団・社団法人は20施設が増加した。特に「自 主事業あり」の施設の増加が顕著である（16施設）注13）。

図3及び表4に示すように「自主事業あり」の比率の変化をみると、 1986調査から1990調查においてはどの種別も増加している。しかし、 1990調査から1995調査においては全体では横ばいで推移しているも のの、個別ではどの種別も僅かに減少している。但しどの種別も1986 調査の水準を下回ってはいない。なお種別の変更のない施設は「自 主事業あり」の比率が比較的小さい。また表5に示すように自主事 業の有無の変化（内訳）をみると、一貫して「自主事業あり」の施 設は全体の6割近くを占める。一貫して「自主事業なし」の施設は 全体の $1 / 4$ 程度存在する。補足調査の結果、「自主事業なし」から 「自主事業あり」となった22施設の中には、種別の変更を契機に自 主事業を開始したケースが含まれる（8施設）注14)。

\section{6. 開館年代との関連}

表6に示すように開館年代と組織種別の関連をみると、1965～75 年 (昭和40年代) までは教育委員会以外の自治体部局が多いが、1975 $\sim 85$ 年（昭和 50 年代）から は教育委員会と財団・社団 法人が多くなり、教育委員 会以外の自治体部局は大き く減少している。また開館 年代と組織種別の増減との

関連をみると（同表）、教育委員会以外の自治体部局は1955 65年 （昭和30年代）以降、どの開館年代も減少しているのに対して、財 団・社団法人はどの開館年代も増加している。種別の変更は1965 75年（昭和 40 年代）が多い。教育委員会については、教育委員会か ら財団・社団法人に種別を変更した施設と、教育委員会以外の自治 体部局から教育委員会に種別を変更した施設の多いことを先に述べ たが、開館年代による差違は認められない。

表7に示すように開館年代と自主事業の有無との関連をみると、 開館年代が古いほど「自主事業あり」の施設の比率は小さい。1955 ～65年（昭和30年代）までは「自主事業なし」の施設が多いが、1965 〜 75年（昭和 40 年代）からは「自主事業あり」の施設が多い。また 開館年代と自主事業の有無の増减との関連をみると（同表）、1965 〜 75年（昭和 40 年代）の施設において「自主事業なし」から「自主 事業あり」となった施設が多い法15)。

\section{7. 機能構成との関連}

表8に示すように機能構成と組織種別の関連をみると、「ホール・ 集会室 $+\alpha 」 は$ 財団・社団法人が多い。「ホール・練習室・展示室・

\begin{tabular}{|c|c|c|c|c|c|c|c|c|c|}
\hline \multirow[t]{2}{*}{ 開館年代 } & \multicolumn{5}{|c|}{ 組織種別 } & \multicolumn{4}{|c|}{ 種別の增減 } \\
\hline & 1 & 2 & 3 & 4 & 合計 & 1 & 2 & 3 & 4 \\
\hline$-1955(-S 30)$ & 0 & 2 & 2 & 0 & 4 & -1 & 0 & 1 & 0 \\
\hline $1955-65(\mathrm{~S} 30-)$ & 7 & 10 & 7 & 1 & 25 & -1 & -4 & 5 & 0 \\
\hline $1965-75$ (S40-) & 17 & 22 & 21 & 3 & 63 & 1 & -11 & 8 & 2 \\
\hline $1975-85(\mathrm{~S} 50-)$ & 41 . & 13 & 32 & 4 & 90 & -1 & -3 & 5 & -1 \\
\hline $1985-(\mathrm{S} 60-)$ & 11 & 1 & 10 & 3 & 25 & 1 & -3 & 1 & 1 \\
\hline 全体 & 76 & 48 & 72 & 11 & 207 & -1 & -21 & 20 & $\overline{2}$ \\
\hline
\end{tabular}

表7開館年代と自主事業の有無 (1995)、有無の增減(1986 $\rightarrow 1995)$

\begin{tabular}{|c|c|c|c|c|c|c|c|}
\hline \multirow[t]{2}{*}{ 開館年代 } & \multicolumn{4}{|c|}{ 自主事業の有無 } & \multicolumn{3}{|c|}{ 有無の增減 } \\
\hline & あり & なL & 合計 & ありの比率\% & あり & な & 比率96 \\
\hline$-1955(-\mathrm{S} 30)$ & 1 & 3 & $\overline{4}$ & 25.0 & 0 & 0 & 0.0 \\
\hline $1955-65(\mathrm{~s} 30-)$ & 9 & 16 & 25 & 36.0 & 2 & -2 & 8.0 \\
\hline $1965-75$ (S40-) & 38 & 25 & 63 & 60.3 & 1 & -7 & 111 \\
\hline $1975-85$ (S50-) & 77 & 13 & 90 & 85.6 & 1 & -1 & 1.1 \\
\hline $1985-(560-)$ & 20 & 5 & 25 & 800 & 3 & -3 & 120 \\
\hline \begin{tabular}{|l|} 
全体 \\
\end{tabular} & 145 & 62 & 207 & 70.0 & 13 & -13 & 6.3 \\
\hline
\end{tabular}


集会室 $+\alpha\rfloor 「$ 「ルル・練習室 $+\alpha 」$ は教育委員会及び財団・社団 法人が多い。「ホール $\alpha 」$ は教育委員会が多い。また機能構成と 組織種別の増減との関連をみると（同表）、「ホール・集会室+ $\alpha 」$

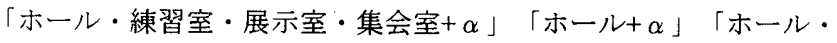
練習室・集会室 $+\alpha 」$ は教育委員会以外の自治体部局から財団・社 団法人に種別を変更した施設が多い。

表9に示すように機能構成と自主事業の有無との関連をみると、 練習室を有する施設の約9割では自主事業を行っている。一方、練 習室のない施設は「自主事業あり」の比率が小さい。練習室はない が集会室を有する施設の半数以上は自主事業を行っていない。また 機能構成と自主事業の有無の増減との関連をみると（同表）、「木

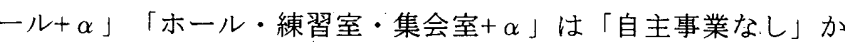
ら「自主事業あり」となった施設が多い洼16)。

\section{8. 施設名称との関連}

表10に示すように施設名称と組織種別の関連をみると、「…公会 堂」は財団・社団法人が多い。「…市民会館」は教育委員会以外の

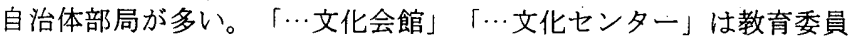
会及び財団・社団法人が多い。「…公民館」はすべて教育委員会で ある注17)。また施設名称と組織種別の増堿との関連をみると（同表）、

$\lceil\cdots$ 市民会館」は教育委員会以外の自治体部局から財団・社団法人 に種別を変更した施設が多い。

表11に示すように施設名称と自主事業の有無との関連をみると、

“..公会堂」は「自主事業あり」の比率がたいへん小さい。「…市 民会館」も「自主事業あり」の比率が小さい。一方、「…女化会館」 は「自主事業あり」の比率がたいんん大きい。「亚文化センタ一」 む「自主事業あり」の比率が大きい。「…公民館」はすべて自主事 業を行っている。また施設名称と自主事業の有無の増减との関連を みると（同表）、「…市民会館」及び「…文化会館」は「自主事業 なし」から「自主事業あり」となった施設が多い。

\section{9. 施設規模との関連}

表12に合計客席数と組織種別の関連を示す。500席未満の施設は 教育委員会及び財団・社団法人が多い。500〜1,500席の施設は教育 委員会が多い。1,500席以上の施設は財団・社団法人が多い。但し 2,000 席以上の施設になると、教育委員会及び教育委員会以外の自 治体部局は大きく減少している。また合計客席数と組織種別の増減 との関連をみると（同表）、1,000 2,000席の施設は教育委員会以 外の自治体部局から財団・社団法人に種別を変更した施設が多い。

表13に合計客席数と自主事業の有無との関連を示す。1,500～ 2,000 席の施設は「自主事業あり」の比率が大きい。また合計客席 数と自主事業の有無の増減との関連をみると（同表）、500席末満 の施設は「自主事業なし」から「自主事業あり」となった施設の比 率が大きい。一方、2,000席以上の施設は「自主事業あり」から「自 主事業なし」となった施設の比率が大きい法18)。

表14に運営床面積と組織種別の関連を示す。 $5,000 \mathrm{~m}^{2}$ 未満の施設 は教育委員会が多い。5,000 $\mathrm{m}^{2}$ 以上の施設は財団・社団法人が多い。 但し $15,000 \mathrm{~m}^{2}$ 以上の施設になると、教育委員会及び教育委員会以外 の自治体部局は大きく減少している。また運営床面積と組織種別の 增減との関連をみると（同表）、 $10,000 \mathrm{~m}^{2}$ 未満の施設は教育委員会

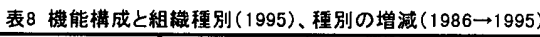

\begin{tabular}{|c|c|c|c|c|c|c|c|c|c|}
\hline \multirow[t]{2}{*}{ 譏能棈成 } & \multicolumn{5}{|c|}{ 組織種別 } & \multicolumn{4}{|c|}{ 種別の増減 } \\
\hline & 1 & 2 & 3 & 4 & 全体 & 1 & 2 & 3 & $\overline{4}$ \\
\hline 木ール・集会室 $+\alpha$ & 10 & 15 & 18 & 4 & 47 & -2 & -8 & 9 & 1 \\
\hline |ホール・練習室·展示室·集会室 $+\alpha$ & 20 & 9 & 21 & 3 & 53 & 2 & $7-5$ & 3 & 0 \\
\hline 木ーn・練習室 $+\alpha$ & 15 & 5 & 14 & 1 & 35 & -4 & 0 & 3 & 1 \\
\hline$\pi-\mu+\alpha$ & 17 & 7 & 5 & 1 & 30 & 1 & -4 & 3 & 0 \\
\hline |木-ル・展示室·菓会室 $+\alpha$ & 7 & 8 & 6 & 0 & 21 & 1 & -1 & 0 & 0 \\
\hline 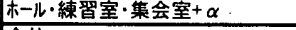 & 7 & 4 & 8 & 2 & 21 & 1 & -3 & 2 & 0 \\
\hline 全体 & 76 & 48 & 72 & 11 & 207 & -1 & -21 & 20 & 2 \\
\hline
\end{tabular}

\begin{tabular}{|c|c|c|c|c|c|c|c|}
\hline \multirow[t]{2}{*}{ 機能構成 } & \multicolumn{4}{|c|}{ 自主事業の有無 } & \multicolumn{3}{|c|}{ 有無の增隇 } \\
\hline & あり & なし & 合斯 & ありの比率 $\%$ & あり & な & 比率\% \\
\hline 木-几・集会室 $+\alpha$ & 17 & 30 & 47 & 362 & -1 & 1 & 2.1 \\
\hline |木ール·練習室·展示室·集会室 $+\alpha$ & .47 & 6 & 53 & 887. & 1 & -1 & 1.9 \\
\hline 木ール・練習室 $+\alpha$ & 31 & 4 & 35 & 38.6 & 1 & -1 & 2.9 \\
\hline 木-ル+a & 18 & 12 & 30 & 600 & 1 & -7 & 233 . \\
\hline $\mid 木-ル \cdot$ 展示室:集会室 $+\alpha$ & 14 & 7 & 21 & 6677 & 2 & -2 & 9.5 \\
\hline 林ール・練習室·集会室 $+\alpha$ & 18 & 3 & 21 & 85.7 & 3 & -3 & 14.3 \\
\hline 全体 & 145 & 62 & 207 & 70.0 & 13 & -13 & 6.3 \\
\hline
\end{tabular}

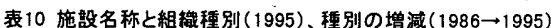

\begin{tabular}{|c|c|c|c|c|c|c|c|c|c|}
\hline \multirow[t]{2}{*}{ 施設名称 } & \multicolumn{5}{|c|}{ 絸織種別 } & \multicolumn{4}{|c|}{ 種別の增減 } \\
\hline & 1 & $\overline{2}$ & 3 & 4 & 全体 & 1 & 2 & 3 & 7 \\
\hline$\cdots$ 公会堂 & 1 & 3 & $5:$ & 0 & 9 & -1 & 2 & 3 & $\overline{0}$ \\
\hline …市民会館 & 16 & 29 & 19 & 3 & 67 & 2 & -13 & 9 & 2 \\
\hline ‥県民会館 & 0 & 1 & 2 & 0 & 3 & 0 & -1 & 1 & 0 \\
\hline - “区町民会館 & 2 & 1 & 2 & 0 & 5 & -1 & 0 & 1 & 0 \\
\hline ..文化会館 & 27 & 4 & 15 & 4 & 50 & -1 & 0 & 1 & 0 \\
\hline ․文化センター & 15 & 4 & 13 & 1 & 33 & 1 & -1 & 0 & 0 \\
\hline …公民館 & 3 & 0 & 0 & 0 & 3 & 0 & 0 & 0 & 0 \\
\hline その他の名称 & 12 & 6 & 16 & 3 & 37 & -1 & (1) & 5 & 0 \\
\hline 全体 & 76 & 48 & 72 & 11 & 207 & -1 & -21 & 20 & $\overline{2}$ \\
\hline
\end{tabular}

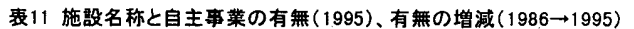

\begin{tabular}{|c|c|c|c|c|c|c|c|}
\hline \multirow[t]{2}{*}{ 施設名称 } & \multicolumn{4}{|c|}{ 自主事業の有無 } & \multicolumn{3}{|c|}{ 有無の增減 } \\
\hline & あり & なL & 合勘 & ありの比率9 & あり & なL & 比率\% \\
\hline ․公会堂 & $\overline{2}$ & 7 & 9 & 22.2 & 1 & -1 & 11.1 \\
\hline ‥⿱亠巾中方民会館 & 35 & 32 & 67 & 522 & 7 & -7 & 10.4 \\
\hline ·県民会館 & 2 & 1 & 3 & 66.7 & -1 & 1 & 33.3 \\
\hline ․区町民会館 & 4 & 1 & 5 & 80.0 & 0 & 0 & 0.0 \\
\hline ․文化会館 & 48 & 2 & 50 & 2660 & 6. & -6 & 120 \\
\hline ‥文化センター & 26 & 7 & 33 & 78.8 & 1 & -1 & 3.0 \\
\hline ‥公民館 & 3 & 0 & 3 & 1000 & 0 & 0 & 0.0 \\
\hline その地の名称 & 25 & 12 & 37 & 67.6 & -1 & 1 & 2.7 \\
\hline 全体 & 145 & 62 & 207. & 70.0 & .13 & -13 & 6.3 \\
\hline
\end{tabular}

以外の自治体部局から財団・社団法人に種別を変更した施設が多い。

表 15 に運営床面積と自主事業の有無との関連を示す。 $20,000 \mathrm{~m}^{2}$ 以 上の施設はす心゙て自主事業を行っている。一方、 $5,000 \mathrm{~m}^{2}$ 未満及び 15,000～20,000 $\mathrm{m}^{2}$ 未満の施設は「自主事業あり」の比率が小さい。 また運営床面積と自主事業の有無の増減との関連をみると（同表）、 $5,000 \mathrm{~m}^{2}$ 末満の施設は「自主事業なし」から「自主事業あり」とな つた施設の比率が大きい。一方、15,000〜20,000 $\mathrm{m}^{2}$ 末満の施設は「自

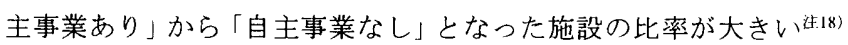

図4に合計客席数と運営床面積の関連を示す。運営床面積が同じ でも合計客席数にはかなりのバラツキが認められる。特に $10,000 \mathrm{~m}^{2}$ 以上の施設においてバラツキが大きい。これはホール機能以外に 様々な機能が複合し、施設を構成していることを意味する。なぜな らホール機能部分の床面積と客席数にはある程度の相関が認められ るからである文10) 刘11)。また、運営床面積が同じでも合計客席数に バラツキが認められることは、ホール機能が主用途である施設と主 用途でない施設が共存する可能性を示している。このことも自主事 業の有無に影響を及ぼしているのではないかと考えられる注19)。

\section{0 . 外的要因}

1980年（昭和55年）から1995年（平成7年）に至る組織種別及び 自主事業の有無の変化に係る外的要因についてみると（図5）、ま ず経済状況については、バブル経済の影響を受けて大きく変動した 
注20)。景気循環を反映し文15)、バブル崩壊後の財政状況は国家・地 方ともに危機的状況にあると言える。地方財政における経常収支比 率注21) や公債費負担比率注22) の変化をみると、景気循環の影響を顕 著に示している文16)。従って、今後もより一層の行財政改革の推進 が求められる。これは組織種別の変化の大きな要因と言える。

次に社会状況については、1994年（平成6年）施行の改正労働基 準法への対応、不況による残業カット等の要因により、年間総実労 働時間注23) はこの間に約200時間も短縮した文14)。一方、自由時間 は増大し、概して余睱重視の傾向にあると言える注24)。従って、施 設利用者のニーズに合ったより柔軟な運営システムの整備が必要で ある。1986調査から1990調査において「自主事業あり」の比率が増 加したが、これら社会状況の変化が要因として挙げられる。

さらに運営組織に対する法制度については、1991年（平成3年） の地方自治法改正に伴い、公の施設の管理を自治体の出資法人に委 託できる旨が明記された。また管理受託者が利用料金を収受できる などの改正が加えられた。1995調查における自治体の直営から財 団・社団法人一の種別の変更は、改正地方自治法の適用によるもの とみなすことができる注25)。

従って、労働時間の短縮や余暇時間の増大等にみられる社会状況 の変化に対応して、施設運営や自主事業等のソフト面の重要性は認 識されているものの、経済状況の悪化や行財政改革に伴う予算削減 のあおりを受けて施策の実施に支障をきたしている状況が窥える。 今後も文化を取り巻く環境（特に財政面）はさらに悪化することが 㲘念され、持続可能な文化政策の策定とその展開が必要である。

\section{1.まとめ}

舞台芸術施設の運営状況における変化の中から、特に運営組織と 自主事業の有無の時系列変化に着目し、開館年代、機能構成、施設 名称、施設規模との関連及び変化に係る外的要因を考察した。

自主事業の有無については、教育委員会及び財団・社団法人に「自 主事業あり」の施設が多く、教育委員会以外の自治体部局は「自主 事業なし」の施設が多い。自主事業の実施は、一概には言えないが、 積極的な施設運営と事業展開を図っているかどうかを示すひとつの 指標とみなすことができる。自主事業の実施は、様々なジャンルの 舞台芸術の上演を可能とする多目的ホールを有効に活用するための ひとつの手段として、一応の評価を下すことができる。

組織種別については、自治体の直営から財団・社団法人に種別を 変更した施設と教育委員会以外の自治体部局から教育委員会に種別 を変更した施設が多い。組織種別の変化は、文化会館あるいは芸術 文化に対する法的根拠の欠如（不明確さ）等が主要な要因となって いることは否めない刘2)文13)。しかし、これは長い目で見れば地域 文化の独自性、自律性、主体性を確立するための文化環境の䤑成を 可能としている。地域文化は、その土地で長年の間培ってきた歴史、 伝統、慣習、風俗、気候、風土等と密接に関係し、一律の法制度に よって細かく規定されるべきものではないと言える注26)。従って、 行政の立場としては主に文化環境の基本的な枠組みの整備（施設整 備を含む）を行うこととし、地域文化活動のいわば補助的な役割を 担うべきではないかと考えられる。地域文化の真の担い手である地 域住民の自発的な団結と努力と䜭智によって、地域文化の質の向上 と発展を図ることが大切である。これは、地域の活性化や 21 世紀の
表 12 合計客席数と組織種別(1995)、理別の增減 (1986 -1995)

\begin{tabular}{|l|cccc|c|ccccc|}
\hline \multirow{2}{*}{ 合計客席数(席) } & \multicolumn{5}{|c|}{ 組鐡種別 } \\
\cline { 2 - 11 } & 1 & 2 & 3 & 4 & 全体 & 1 & 2 & 3 & 4 \\
\hline-500 & 5 & 1 & 5 & 2 & 13 & -1 & -1 & 2 & 0 \\
$500-1,000$ & 28 & 16 & 12 & 0 & 56 & -1 & -2 & 3 & 0 \\
$1,000-1,500$ & 25 & 15 & 17 & 5 & 62 & 0 & -9 & 8 & 1 \\
$1,500-2,000$ & 17 & 12 & 22 & 3 & 54 & 1 & -8 & 7 & 0 \\
$2,000-$ & 1 & 4 & 16 & 1 & 22 & 0 & -1 & 0 & 1 \\
\hline 全体 & 76 & 48 & 72 & 11 & 207 & -1 & -21 & 20 & 2 \\
\hline
\end{tabular}

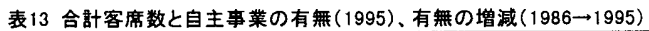

\begin{tabular}{|l|ccc|c|cc|c|}
\hline \multirow{2}{*}{ 合計客席数(席) } & \multicolumn{3}{|c|}{ 自主事莱の有無 } & \multicolumn{3}{|c|}{ 有無の增減 } \\
\cline { 2 - 9 } & あり & なし & 合計 & ありの比率\% & あり & なし & 比率9 \\
\hline-500 & 9 & 4 & 13 & 69.2 & 4 & -4 & 30.8 \\
$500-1,000$ & 35 & 21 & 56 & 62.5 & 4 & -4 & 7.1 \\
$1,000-1,500$ & 41 & 21 & 62 & 66.1 & 4 & -4 & 6.5 \\
$1,500-2,000$ & 45 & 9 & 54 & 83.3 & 4 & -4 & 7.4 \\
$2,000-$ & 15 & 7 & 22 & 68.2 & -3 & 3 & 13.6 \\
\hline 全体 & 145 & 62 & 207 & 70.0 & 13 & -13 & 6.3 \\
\hline
\end{tabular}

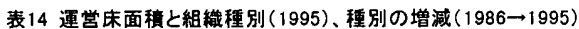

\begin{tabular}{|c|c|c|c|c|c|c|c|c|c|}
\hline \multirow{2}{*}{ 運党床面程 $\left(\mathrm{m}^{2}\right)$} & \multicolumn{5}{|c|}{ 組織䅜別 } & \multicolumn{4}{|c|}{ 種別の增減 } \\
\hline & 1 & 2 & 3 & 4 & 全体 & 1 & 2 & 3 & 4 \\
\hline$-5,000$ & 47 & 19 & 23 & 3 & 92 & $\overline{0}$ & 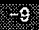 & 10 & -1 \\
\hline $5,000-10,000$ & 23 & 20 & 29 & 6 & 78 & -2 & 8 & 8. & 2 \\
\hline $10,000-15,000$ & 5 & 9 & 13 & 2 & 29 & 0 & -3 & 2 & 1 \\
\hline $15,000-20,000$ & 0 & 0 & 5. & 0 & 5 & 0 & 0 & 0 & 0 \\
\hline 20,000 & 1 & 0 & 2 & 0 & 3 & 1 & -1 & 0 & 0 \\
\hline 全体 & 76 & 48 & 72 & 11 & 207 & -1 & -21 & 20 & 2 \\
\hline
\end{tabular}

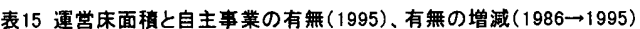

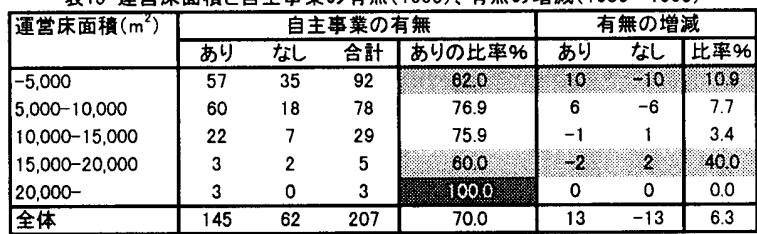

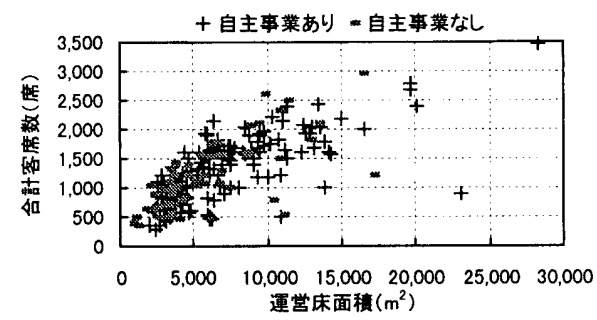

图4 合部客席数と運営床面糟

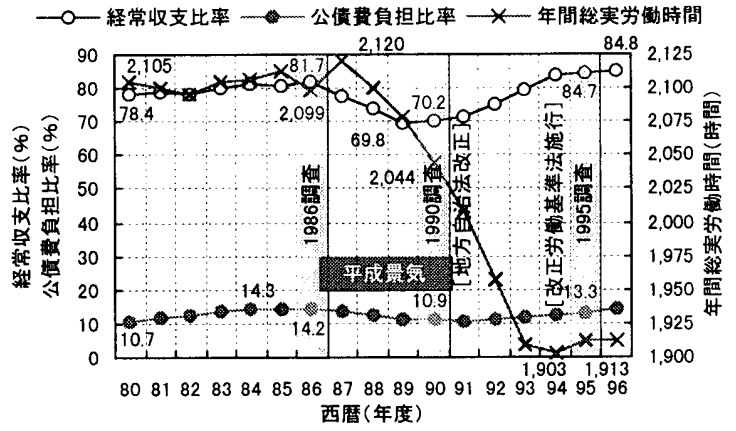

注: 1980 及び調查年度の数値と1980 95及び96年度の最大値·最小値を示した。 経常收支比率、公供费負担比率は全国加重平均。経常収支比率は特別区及び

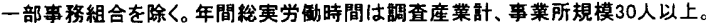
出典 : 自治省「地方財政白書」、労趿省「每月勤労統部裯查」 图5 組辆種別及び自主事菜の有無の变化に係る外的要因

高齢社会に向けて重要な視点である。

謝辞 1986 調査以来、本ブロジェクトに関わる多くの研究者ならでに有識者 の皆様には厚く御礼申し上げる。アンケート調査の実施にあたっては、各小 ール担当者の皆様から多大なるご協力を得た。ここ改めて感謝の意を表才

注

1）1990調査に先立ち、舞台芸術施設運営に関するアンケート調査の母集団 となる舞台芸術施設データベースを作成するためのアンケート調査を実施し

た。調查対象は全国公立文化施設協会名簿（1988）、全国ホール名鑑（1986） 
に記載された施設を基本とし、びあホールmap (1991) をはじめとする各種 情報誌、電話帳、その他の資料から得られた全国の舞台芸術施設と思われる 2,134施設で1,323施設から回答を得た。調查結果は「舞台芸術施設データべ 一ス（1994.03）」としてまとめられた。これは当時の最も広範で詳細な舞 台芸術施設リストである

2）1990調查には一部民間の施設も含まれているが、1986調査が公立の施設 のみを対象としたので、1995調查は結果的に公立の施設のみを对象とするこ ととなった

3）1990調查の中で作成した「舞台芸術施設データベース（1994.03）」には、 公立の施設として約 1,500 施設を収録している。従うて、1995調查の時系列 標本（207施設）ばそのうちの約 $14 \% に$ 相当する。

4）組織種別を変更した40施設に対しては、郵送による変更の理由等を尋衫 る補足調查を行った。

5）ここで用いる財団・社団法人は、主に民法34条に規定される公益法人を 示寸が、特別法に基づく公益法人を含む（社会福祉法人等）。

6）その他の種別には広域市町村組合や施設管理公社等が含まれる。

7）アンタート調査ではホールごとに自主事業日数、共催事業日数、贷館利 用日数、貸館空き日数、休館整備日数をそれぞれ記入することとしている

8）本研究では、公演のリスク配分に関わらず、会館独自が企画する催しを

自主事業と定義する。但し、他会館で行われた自主事業、ホールを使用しな い自主事業（展示等）、共催事業であることが明らかなものを除く。

9）ホール機能を管理運営する組織が管理運営にあたる機能として、「ホー ル機能」「練習室 (リハーサル室) 機能」「ギャラリー（展示室）機能」「図 書・情報サービス機能」「集会室機能」「生涯学習関連機能」「公民館関連 機能」「スポーツ関連機能」「宿泊関連機能」「その他の諸機能」を設定し た。「その他の諸機能」には結婚式場等が含まれる。付表1をみると、ホー ル機能の他に集会室機能、練習室.(リハーサル室)、機能、ギャラリー（展示 室）機能が多い。まずこれら4つの機能の組み合わせで施設を分類した。

10）付表2に示すように機能構成（複合形態）をみると、「ホール・集会室 が最も多く、以下、「ホール・練習室・展示室・集会室」「ホール・練習室」 「ホール」「ホール・展示室・集会室」「ホール・練習室・集会室」「ホー ル・練習室・展示室」の順となっている。「その他の組み合わせ」が多いの で、付表3に示すように付表 2 の上位6つの基本型に基本形以外の諸機能を +

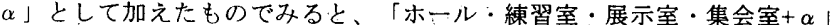

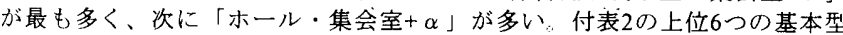
によってす心゙ての施設を分類し直した。この操作によって機能構成を包括的 に把握することが可能となった。なお、付表 2 のホール・練習室・展示室

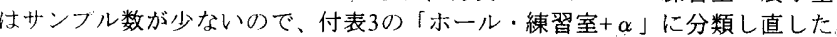
11）但し、客席数はオークストラピ.ット部分等の可動席がある場合はそれを 含めた最大檤と寸る（補助席を除く）

12）この要因としてまず教育委員会は、社会教育法の枠組みの中で様々な事 業を行うための法的根拠が整備されており、長年の豊富な夷緢のあることを 指摘寸ることができる。また財団・社団法人は多くの場合、総合的な視野か ら地域文化の創造や発展を目的として設置されるのであるからら「自主事業 あり」の施設が多いのはむしろ当然である。これに対して教育委員会以外の 自治体部局は、事業に対する法的な裏付けがないこと、実績にそしいこと、 昨今の財政難や行財政改革による職員定数の削減等の要因で、積極的な事業 展開を図ることが困難になって いるのではないかと考えられる。 13）補足調查等の結果、教育委 員会以外の自治体部局において 岋、開館当初は首长主導のもと、 社会教育の枠をこえた芸術文化 あるいは生活文化の振興を自的 として設置されたものの、法的 根拠が整備されている社会教育 の延長線上で事業を行った方が 予算を獾得する上で有利なこと

また第三者機関に委託した方か 市民により柔軟できめの細がな サーービスを提供できることなど から、教育委員会あるいは財団 ・ 社団法人に種別の変更を余儀な くされたど考えることができる。 また、教育委員会以外の自治体 部局から教育委員会八の種別の 変更は、文化行政の一元化の動 きともとれる

14）補足調查の結果、種別の変 更と「自主事業あり」への変更 の時期が一致するケースが羿め られる。

15）1985年以降（昭和60年代） において自主事業の有無の增减 の比率が大きいのは、1986調査 において開館前あるいは開館し て間もない施設で本格的な運営
を行っていない（運営夷 績がない) ケースを含む ためである。

16）練習室（リハーサル 室）を有するということ は施設の理念として舞台 芸術の上演及び発表を意 图して計画されたという ことである。付表4に示 すように舞台設備の有無 と自主事業の有無との関 連をみると、「自主事業 あり」の施設は「自主事 業なし」の施設より舞台 設備が充実している。舞 台設備の有無の観点から みて、舞台設備が整って いないということは舞台 芸術の上演及び発表を自 主事業として行いたくて も満足に行うことができ

\begin{tabular}{|c|c|c|c|c|}
\hline 舞台設䔣の有無 & \multicolumn{4}{|c|}{ 自主事業の有無 } \\
\hline 暗天稓 & あり & なL & 合尌 & ありの比率\% \\
\hline 設㒂 あり & 114 & 42 & 156 & 731 \\
\hline 設備なし & 27 & 19 & 46 & 58.7 \\
\hline 手動バトン & あり & なL & 合計 & ありの比率 $\%$ \\
\hline 設備あり & 138 & 56 & 194 & 711 \\
\hline 設備なし & 3 & 5 & 8 & 37.5 \\
\hline 電動バトン & あり & な & 合咶 & ありの比率\% \\
\hline 殷備あり & 90 & 33 & 123 & 732 \\
\hline 設菕なし & 51 & 28 & 79 & 64.6 \\
\hline オーケススラピット & あり & なし: & 合斯 & ありの比率 \% \\
\hline 段偌あり & 56 & 10 & 66 & 848 . \\
\hline 設備なし & 85 & 51 & 136 & 62.5 \\
\hline 通以回以舞台 & あり & なL & 合阜 & ありの比率\% \\
\hline 設侑あり & 53 & 16 & 69 & 768 \\
\hline 設備なし & 88 & 45 & 133 & 66.2 \\
\hline 音䇾反射板 & あり & な & 合計 & ありの比率9 \\
\hline 殷菕あり & 133 & 46 & 179 & 743 \\
\hline 設佂なし & 8 & 15 & 23 & 34.8 \\
\hline 不明 & 4 & 1 & 5 & 80.0 \\
\hline 全体 & 145 & 62 & 207 & 70.0 \\
\hline
\end{tabular}

ないということであり、プロの上演組織を呼びたくても呼べない状況にある と考えられる。また、そもそも施設の理念として舞台芸術の上演及び発表を 意図して計画されていないといったケース等も考えられる。

17）公民館は社会教育法に基づく社会教育施設である

18）この中には阪神大震災の影響で休館となった施設が含まれる

19）合計客席数及び運営床面積がともに小さい施設に「自主事業なし」の施 設が比較的多く存在する

20）経済企画庁は「平成景気は1986年12月から1991年4月までの)53个月で、 期間の長さとしては、いざなぎ景気の57ケ月に次いで戦後2 番目の大型景気 であった」と認定している

21）経常収支比率=経常経費充当一般財源/経常一般財源総額

22）公債費負担比率 $=$ 公債費充当一般財源 $/$ 一般財源総額

23）残業を含む労働者 1 人当たりの年間労働時問

24）1990年（平成2年）には「生涯学習の振興のための施策の推進体制等の 整備に関する法律」が施行された

25）1991年（平成3年）の地方自治法改正以前も財団・社団法人八刀種別の 変更は制度上可能であり、法改正は世の中の流れに追随する形ともとれる 26）文化財保護等、法律の制定が特に有効な場合もある。

\section{参考文献}

1）山崎正和 (研究代表者)：舞台芸術施設の経営に関寸る研究一㓺場施設の 経営に関寸る計量モデルの作成、昭和61-63年度科学研究費補助金研究成果 報告書、 1989

2）永山貞則(研究代表者)：舞台芸術施設データベース、文化・芸街情報研 究会、 1994

3）清水裕之(研究代表者)：ミクロ統計デー夕を活用した舞台芸術施設運営 に関寸る調查研究、平成8年度科学研究費補助金研究成果報告書、1997

4）清水裕之(研究代表者)：ミク口統計デー夕を活用した舞台芸術施設運営 に関寸る調查研究、平成9年度研究成果報告書、1998

5）清水裕之：文化会館の構造転換－必要性とその方向、学位論文、1982

6）清水裕之：文化会館をめぐる文化行政一「文化振興会議」にみる文化行 政と文化会館その1、日本建築学会計画系論文報告集 No.392、pp.60-71、1988 7）清水裕之：文化会館をめぐる文化事業一「文化振興会議」にみる文化行 政と文化会館その2、日本建築学会計画系論文報告集 No.402、pp.31-43、1989 8）守屋秀夫、清水裕之、小野田泰明: 劇場・ホールの施設と運営の現状一 運営組織（自治体、財団法人、民間）による相違、世界劇場会議発表論文集、 pp.l-71-82、1993

9）小野田泰明、菅野實、松本啓俊：新設ホールによる都市内文化ホールの 使用変化一仙台市にお计る事例的考察、日本建築学会計画系論文報告集 No.491、pp.83-90、1997

10）清水裕之、新實吉宏 : 公共現代舞台芸術施設の規模計画に関寸る研究、 日本建築学会計画系論文報告集 No.476、pp.81-90、1995

11）清水裕之、新實吉宏 : 公共現代舞台芸術施設の延床面種と容積の推定方 法に関寸万研究一公共現代舞台芸術施設の規模計画に関す万研究 その2 日本建築学会計画系論文報告集 No.503、pp.115-122、1998

12）根木昭、枝川明敬、垣内恵美子、大和滋 : 文化政策概論、晃洋書房、pp.51-75、 1996

13）根木昭、枝川明敬、垣内恵美子、笹井宏益：文化会館通論、晃洋書房、 pp. $27-42 、 1997$

14）（財）余睱開発センター：レジャー白書'96、1996

15）增井喜一郎編：図説 日本の財政 平成 10 年度版、東洋経済新報社、 pp.168-169、1998

16）島津昭編：図説 地方財政 平成10年度版、東洋経済新報社、pp.270-275、 1998 